\title{
Measuring the Urgency of Draft Legislation on the Recognition and Protection of Indigenous People from Economic Analysis of Law Perspective
}

\author{
Anti Mayastuti ${ }^{1}$, Jamal Wiwoho ${ }^{2}$, Hari Purwadi ${ }^{3}$ \\ ${ }^{1.2 .3}$ Universitas Sebelas Maret \\ Surakarta, Indonesia \\ antimayastuti@staff.uns.ac.id
}

\begin{abstract}
The purpose of this study is to determine the effectiveness of economic theory against law to measure the urgency of the Draft Legislation on the Recognition and Protection of Indigenous People in developing Pancasila Economic Law System. This research is a doctrinal legal research by combining law as a science thats argumentative, logical, and hermeneutical discipline. In the current era, the direction and objectives of political economy law must be focused on the creation of a legal system capable of providing economic justice to the community. There are three steps that must be taken, such as : legal development must be carried out revolutionarily, in a sustainable manner and is carried out using an economic approach. Development in the field of economic law is needed by providing space for the recognition and protection of indigenous people which is done first through the drafting of recognition and protection of indigenous people bill, then promulgate it, so that in the future it can reduce agrarian conflicts involving indigenous peoples, which until now reaches 1400 conflict cases, and reduce the phenomenon of poverty that afflicts 40-60 million indigenous people.
\end{abstract}

Keywords- Draft Legislation, Indigenous People, Economic Analysis of Law.

\section{INTRODUCTION}

In this case, customary law is equated with "indigenous law", which is an unwritten law that has been owned and applied to MHA since before Indonesia's independence. Adat in Indonesia has become an umbrella term to denote the often undifferentiated whole that is shaped by the morality, customs, and legal institutions of ethnic or territorial groups. [1]

The most widely accepted definition appears to be that of the UN Special Rapporteur on Discrimination against Indigenous Peoples, Martínez Cobo, from 1983, which defines indigenous peoples as follows: Indigenous communities, peoples and nations are those which, having a historical continuity with pre-invasion and pre-colonial societies that developed on their territories, consider themselves distinct from other sectors of the societies now prevailing in those territories, or parts of them. They form at present non-dominant sectors of society and are determined to preserve, develop and transmit to future generations their ancestral territories, and their ethnic identity, as the basis of their continued existence as peoples, in accordance with their own cultural patterns, social institutions and legal systems. [2]
As for indigenous peoples, it is further regulated in laws governing natural resources, including Law No. 41 of 1999 concerning Forestry, Law No. 22 of 2001 concerning Oil and Gas, Law No. 27 of 2003 concerning Geothermal Energy, Law No. 18 of 2004 concerning Plantations, Law No. 31 of 2004 concerning Fisheries, Law No. 27 of 2007 concerning Management of Coastal Areas and Small Islands as amended by Law No. 1 of 2014, Law No. 30 of 2009 concerning Electricity and so on.

Those vital objects regulated in various laws are connected to the economic resources for indigenous people to fulfill their livelihood, and it has been controlled for generations. This is what was claimed to be the sources of state income used for the greatest prosperity of the people based on Article 33 of the 1945 Constitution. Customary law cannot independently guarantee claims to customary land, including natural wealth, even though recognition of MHA is constitutional. Therefore, customary law requires harmonization with state law. Harmonization is needed in many areas of life because customary law in some fields experiences a paradox with state law. [3]

Those central government policies in the utilization of natural resources are suspected to be the one causing endless conflict between government, private sector and indigenous peoples. The cases of agrarian conflicts involving indigenous people have so far reached 1400 cases resulting poverty phenomenon in indigenous people with total numbers of 40-60 million indigenous peoples. Which is why, one of the urgency for issuing Draft Legislation on the Recognition and Protection of Indigenous People (hereinafter referred as PPMHA Bill) is to establish legal unification to accommodate the diversity of indigenous people regulations in Indonesia, in order to realize economic justice for indigenous people

In the current era, the direction and objectives of economic law policy must be focused on the creation of a legal system. Which capable of providing economic justice to the community. To achieve this goal there should be a new approach to build the quality of economic law which contain the spirit of Pancasila and 1945 Constitution.

There are three steps that must be taken, first, the development of law must be carried out revolutionarily, which mean consciously and fundamentally changing the 
economic legal system that so far is based on a liberal philosophy into a family or populist economic system; second, legal development is carried out in a sustainable manner that instigates the public to think of legal development model that has a broader dimension than merely issueing laws and improving legal entities and institutions function; third, legal development is carried out using an economic approach means it should use economic considerations to solve legal problems, including in compiling legislation of economic field must also meet the principles of economic law.

Thus, development in the field of economic law is needed by providing space for the recognition and protection of indigenous people which firstly done through the drafting of recognition and protection of indigenous people bill, then promulgate it, so in the future it can reduce agrarian conflicts involving indigenous peoples.

\section{RESEARCH METHOD}

Mark Van Hoecke propose seven concepts of legal science doctrine namely a) hermeneutic discipline, b) argumentative discipline, c) empirical discipline, d) explanatory discipline, e) axiomatic discipline, f) logical discipline, g) normative discipline. [4] These various doctrinal disciplines have different methodological implications. In connection with this distinction, this research intends to combine law as a science thats argumentative, logical, and hermeneutical discipline. By selecting those three disciplines in the legal science doctrine, this research has more than one dimension. This study also uses a doctrinal approach, which based on primary and secondary legal materials. [5] Data analysis was performed by qualitative non-positivistic approach using the futuristic interpretation method (interpretation of regulations that do not legally binding force yet), and hermeneutic interpretation is interpretation of legal texts is not solely concentrate on the formal legal aspects textually, but also viewed from the context of the past in terms of socio-political, cultural [6] and present contexts.[7]

\section{FINDINGS AND DISCUSSION}

\section{The Urgency of the Draft Legislation on Recognition and Protection of Indigenous People}

Hans Kelsen explains that there are two actions in defining recognition: a) the political act of recognizing a country, means that the state recognizes its intention to enter into political relations and other relations with the community that it recognizes; b) the legal act of recognition which determined by international law to establish state facts in a concrete case". [8] John Austin interpreted recognition through state law as a law made by people or institutions that have sovereignty.

Post-modern perspective that provides diversity so that subjects can interact in competitive social spaces, is supported by recognition politic of indigenous people as legal, social and political subjects whose existence and rights must be protected. Charles Taylor defines recognition in two senses: "universalism politics", means protection of individuals, groups or communities autonomy by guaranteeing their rights; and "politics of difference", namely protection of individuals, groups or communities identity by respecting and allowing them to practice their culture. [9] In another occasion, Axel Honneth suggests recognition in two senses, namely respecting the equality of status and position; and respect for diversity or uniqueness. [11]

Terms of protection coming along with certain rights that have to be safeguarded and respected. Satjipto Rahardjo refers to rights as authorities granted by law to someone in order to protect one's interests. Legal protection from state always emphasizing on the form of protection, unfortunately in reality not all state law can provide protection for one's rights. [12] In the recognizing and protecting indigenous people, the definition of protection element means the prohibition for anyone to take or control the property of others without legal reason.

Customary law that is in harmony with state law is a necessity because customary law reflects part of the rights of indigenous peoples to determine their own destiny (rights to self-determination). From the experience of Africans, the confluence of different interests influences customary law. It was also coupled with the influence of socio-economic forces, thus creating contemporary African customary law. [13] Thus the community has the right to be protected by anyone and anywhere against the land resources owned. [14]

a. The element of recognition is formulated in the provisions in various laws and regulations on the existence of the rights of indigenous people, and even those rights are seen as human rights that must be protected.

b. The element of protection is manifested in the form of concrete actions from the government on behalf of the state, to place individual rights and community rights in their proper position based on the principle of proportionality

c. The element of will means that the indigenous people are respected and appreciated as part of their human rights, thus the law has given the community the right to obtain protection for their nature.

Philipus M. Hadjon states that in formulating the principle of legal protection for the people (in Indonesia) must be based on the principle of recognition and protection of human dignity based on the Pancasila and the principle of the rule of law based on the Pancasila. Recognition of indigenous peoples existence and their traditional rights which are then formulated in the PPMHA Bill is important as a form of state action. By granting legal status to them, it gives the consequence that recognition is carried out thoroughly and comprehensively, towards the unity of indigenous people including all their inherent traditional rights.

In this case, the urgency of PPMHA Bill establishment of the are: [15] 
a. Choice of concepts or terms between indigenous peoples or adat law communities as referred to in 1945 Constitution and several laws;

b. The existence of indigenous people in the constitution and regulations is not in accordance with social reality;

c. Marginalization of indigenous people in the policies of centralized national legal development;

d. Opportunities to empower indigenous people in reformation era;

e. Limit the authority of the subject and object of indigenous people rights protection in national legislation policy;

f. Preventing disintegration and strengthening the commitment of the people and nation to the unitary state of Indonesia by preserving the values of local wisdom;

g. Minimilizing and attempt to form a comprehensive understanding of the basic concepts of distinct communities or indigenous peoples;

h. Creating juridical guidelines so that national legislation policies on the protection of indigenous people rights;

i. Codifying laws or regulations related to the rights of indigenous people to preserve local values;

\section{Economic Analysis of the Law on the Urgency of the Draft Legislation on the Recognition and Protection of Customary Law Communities}

The establishment of the PPPMHA Bill based on an economic analysis of the law, from the Pareto Efficiency perspective indicates that the PPMHA Bill was formed with the aim of building a legal unification that to accommodate the diversity of indigenous people in Indonesia. In addition, the presence of the PPMHA bill can provide guarantees of legal certainty to indigenous people and their traditional rights. The PPMHA bill can also be a national guideline for the drafting of regional regulations based on customary law that grows and develops in various provinces and districts /cities in Indonesia. Economic analysis of law is built on the basis of several general economics concepts, including a) utility maximization, b) rationality, c) stability of preferences and opportunity cost, d) distribution. [16]

On the basis of the economic concept, an economic analysis of law builds a new assumption: "man will rationally try to achieve maximum satisfaction for himself". The reasoning is that in every aspect of life, humans must make certain decisions, because human by nature has unlimited desires while the various available resources for human needs are very limited. If one choice can get him more than other's choice, then he will make the best and efficient choice for himself and be consistent with his choice. However, the problem of how to make choices to achieve efficiency in the use of various resources and achieving maximum satisfaction is the focus of microeconomic analysis.[17]

Richard A. Posner defines efficiency as "to denote the allocatin of resources in which value is maximized", but in the context of economic analysis, he adds that efficiency in this case is limited to ethical criteria in the context of the of social decision making which concerns the regulation of public welfare.[18]

There are several concepts of economic efficiency, First, Pareto Efficiency or often called Pareto Optimality concept of economic efficiency which question whether a policy or a change in the law makes a person better by not causing another person's position to be worse. Second, Kaldor-Hicks Efficiency whose essence is to question whether a policy or change will produce sufficient benefits for those who experience the change, or in other words whether the change provides a balanced compensation to those who are harmed due to the policy or legal changes. This approach is also known as an approach on the basis of cost and benefit analysis. Usually, laws that aim to advance economic efficiency within a free market framework are realized in the form of government interferency in various forms of public policy. [19]

It is also plainly obvious that based on Pareto Efficiency, the passing of PPMHA Bill will not have a negative impact on the lives and interests of the people, nation and other actors. In fact, the effectiveness of the PPMHA Law allegedly can reduce conflicts between indigenous people and the government, corporations and various other parties. Another result of PPMHA Bill based on the Kaldor-Hicks Efficiency is that the promulgation of the PPMHA Bill will produce sufficient benefits for indigenous people. They can freely live without the burden of discrimination, coexist and be equal to other Indonesian citizens. Indigenous people would then realize their ideals of political sovereignty and determine their own life goals and ways to achieve them.

Some principles of Economic Economy Analysis in legislation making in Indonesia are a single unit and cannot stand alone, and can be applied in the drafting of the PPMHA Bill are as follows: [16]

\section{a. Equilibrium Composition Principle}

In legislation drafting, a common definition, perception and purpose are needed between the interests of people in general community perspective and the interests of people in people's representatives perspective.

\section{b. Gap-Filling Principle}

This principle emphasizes the role of law enforcement officials and legal users in realizing, using and applying the provisions of the law itself.

\section{c. Hypothetical Bargains Principle}

This principle emphasized on the effectiveness of legal provisions which used as supporting tools in accordance with their substance.

\section{d. Correlated Productive Principle}

This principle emphasized on the level of productivity of legal regulationts through increasing legal awareness to all levels of society about legal sanctions existence against any act of legal deviation. 
It is undeniable that indigenous people are a party of group who earn very low income due to the deprivation of agrarian rights by the state or other parties legalized by the state. Therefore, one of the urgency PPMHA Bill is to bring justice and prosperity to indigenous people. This is in accordance with the goal of every economic activity is to realize economic justice that ought every group and individual in society enjoy the results of economic activity fairly and equally. This is consistent with Posner's opinion that humans are always given the choice to get satisfaction or economic happiness, which in turn is aimed at increasing wealth (wealth maximizing). One of the effort to increase the prosperity of indigenous people is the establishment of the PPMHA Bill which then followed by its promulgation as soon as possible.

\section{IV.CONCLUSION}

Based on the economic analysis of the law, the PPMHA Bill meets the concept of the economic conception of justice, which is the concept of justice as an economic standard based on three elements, consist of value, utility and efficiency. Thus law is created, applied and used for the main purpose of increasing the public interest as widely as possible. As an implementation, the principles of equilibrium composition, gap-filling, hypothetical bargains, correlated productive, and extensive ken can be applied in the drafting of the PPMHA Bill. Hence, PPMHA Law can later be applied efficiently, effectively and economically, obeyed by the community and in the future would have an impact on reducing agrarian conflicts involving indigenous people.
[11] Satjipto Rahardjo, 1986. Ilmu Hukum. Bandung : Alumni, 1986.

[12] Diala, A. C., \& Kangwa, B. (2019). Rethinking the interface between Customary Law and Constitutionalism in sub-Saharan Africa. De Jure. https://doi.org/10.17159/2225-7160/2019/v52a12

[13] Jawahir Thonthowi, Hukum Inklusif Perspektif Indonesia, Yogyakarta : Kreasi Total Media, 2019.

[14] Johny Ibrahim, Pendekatan Ekonomi Terhadap Hukum Teori dan Implikasi Penerapannya dalam Penegakan Hukum, Surabaya : Putra Media Nusantara \& ITSPress. 2009.

[15] Sadono Sukirno, 1994, Pengantar Teori Mikroekonomi, Jakarta : Raja Grafindo Persada, 1994.

\section{REFERENCES}

[1] Von Benda-Beckmann, F., \& Von Benda-Beckmann, K. (2011). Myths and Stereotypes about Adat Law: A Reassessment of Van Vollenhoven in the Light of Current Struggles over Adat Law in Indonesia. Bijdragen Tot de Taal-, Land- En Volkenkunde. https://doi.org/10.1163/22134379-90003588

[2] Hauser-Schäublin, B. (2014). Adat and Indigeneity in Indonesia: Culture and Entitlements between Heteronomy and Self-Ascription. Journal of Social Issues in Southeast Asia. https://doi.org/10.1355/sj29-3n

[3] Bedner, A., \& Arizona, Y. (2019). Adat in Indonesian Land Law: A Promise for the Future or a Dead End? Asia Pacific Journal of Anthropology. https://doi.org/10.1080/14442213.2019.1670246

[4] Mark van Hoecke, Legal Doctrine : Which Method ( $s$ ) for What Kind of Discipline? in Mark van Hoecke (ed), Methodologies of Legal Research, Which Kind of Method for What Kind of Discipline. Oxford : Hart Publishing, 2011.

[5] Peter Mahmud Marzuki, Penelitian Hukum, Jakarta:Kencana Prenada Media, 2013.

[6] Jazim Hamidi, Hermeneutika Hukum : Sejarah, Filasafat dan Metode Tafsir, Malang : UB Press, 2011.

[7] Gregory Leyh, Legal Hermeneutics, Bandung : Nusa Media, 2011.

[8] Husen Husen Alting, 2011. Dinamika Hukum dalam Pengakuan dan perlindungan Hak Masyarakat Hukum Adat atas Tanah, Yogyakarta : Yogyakarta, 2011.

[9] Otje Salman Soemadiningrat, Rekonseptualisasi Hukum Adat Kontemporer. Bandung : Alumni. 2002.

[10] Axel Honneth. The Struggle for Recognition: The Moral Grammar of Social Conflicts, Cambridge, Massachusetts: The MIT Press. 1996. 